\title{
Chronic case management: Clinical governance with cost reductions
}

Élide Sbardellotto Mariano da Costa ${ }^{1 *}$, Adriano Hyeda ${ }^{2}$

${ }^{1}$ Medical Audit, Fundação Unimed. Cardiologist by Pontifícia Universidade Católica do Paraná (PUC-PR). Executive MBA in Health Administration by Instituto Superior de Administração e Economia/

Fundação Getulio Vargas (ISAE/FGV), Curitiba, PR, Brazil

${ }^{2}$ Occupational Health Coordinator, PUC-PR. Oncologist, Universidade Federal do Paraná (UFPR). Executive MBA in Health Administration by ISAE/FGV, Curitiba, PR, Brazil

Study conducted at the Executive Master Business Administration (MBA) in Health Program, Group 1/12, Lato sensu graduate degree - Specialization level, FGV Management Program, Instituição Superior de Administração e Economia/Fundação Getulio Vargas, Curitiba, PR, Brazil

Article received: 9/8/2014

*Correspondence: Address: Rua José Loureiro, 195, $12^{\circ}$ andar, Centro,

Curitiba, PR - Brasil Postal code: $80010-000$ Phone: +55 41 3330-6110 elide@onda.com.br

http://dx.doi.org/10.1590/1806-9282.62.03.231 Accepted for publication: 9/9/2014

\section{SUMMARY}

Introduction: With increasing global impact of chronic degenerative non-communicable diseases (CDNCD), multidisciplinary chronic disease management care programs (CDMCP) come as a solution to improve the quality of patients care. Method: We conducted a cross-sectional epidemiologic prospective cohort study with data comparing a group of patients monitored by a CDMCP with subjects without CDMCP care, from 2010 to 2012. The patients monitored in this program were selected because they presented CDNCD with frequent hospitalization and/or emergency care in the year prior to study selection. Also, the patients could be referred to the program by their physicians and/or other programs such as HomeCare or family medicine. All costs related to the program were included and compared with the costs of users with the same epidemiological profile who opted for not participating in the CDMCP.

Results: We analyzed data from 1,256 cases, including 639 (51\%) men and 617 (49\%) women. The mean age was 56.99 years and $73 \%$ were older than 50 years. There was a prevalence of $34 \%$ (428) cases with ischemic heart disease (myocardial infarction and stroke) and 17\% (210) with neoplasms. The cases studied showed a reduction of $79 \%$ in the number of days of hospitalization compared with the cases without CDMCP monitoring. The average reduction of total costs (hospitalizations, emergency room visits and/or disease complications) was $31.94 \%$, with average reduction of $8.36 \%$ in monthly costs.

Conclusion: Multidisciplinary monitoring carried out by CDNCD patient management programs can reduce hospitalizations, emergency room visits and complications, positively impacting the costs with health care.

Keywords: chronic disease, health management, health care costs, clinical governance.

\section{INTRODUCTION}

Case management

By the mid 1980s, North American hospitals began facing financial constraints. ${ }^{1}$ In the same context, in Brazil since the beginning of the 1990s, it became a challenge for managers of health plans to offer a quality service to their beneficiaries, seeking to maintain financial sustainability.

The provision of health care is based on three guidelines: management, measurement and qualification. ${ }^{2}$ Management includes primary care, clinical guidelines, pathology management, case management, clinical risk management, hospitalization management, waiting list, the customer service center, and audits. ${ }^{3}$
Case management, specifically, is a cooperative process that is undertaken between the case manager, their multidisciplinary team and the client, in order to plan, monitor and evaluate options and services, according to the health needs of the patient. ${ }^{4}$ It is a system of vertical and horizontal integration. Its main work instrument is communication with the user. ${ }^{1}$

Chronic degenerative and non-communicable diseases (CDNCD) In recent decades, Brazil has presented important transformations in its pattern of mortality and morbidity due to changes in demographic, epidemiological and nutritional profiles. This phenomenon also accompanied the growth of the elderly population and reduction in child 
malnutrition, with a large increase in the number of obese and/or overweight people, increasing the CDNCD. The World Health Organization (WHO) ${ }^{5}$ defines CDNCD as primarily cerebrovascular and cardiovascular diseases, $d i$ abetes mellitus, obstructive lung diseases, asthma and neoplasms, in addition to mental and neurological disorders; oral, bone and joint procedures; genetic disorders; eye and hearing pathologies. This set of diseases has various common non-modifiable risk and behavioral factors that can be managed together. ${ }^{6}$

\section{Economic evaluations}

According to Alliota, ${ }^{7}$ multidisciplinary chronic disease management care programs (CDMCP) produce 60\% reduction in demand for hospital services, $50 \%$ reduction in hospitalizations, and increased user satisfaction. In this context, according to Lynce $2007,85 \%$ of chronically ill patients consumed $30 \%$ of inpatient costs in Portugal. With quality management it is possible to obtain values as significant as a $40 \%$ reduction in hospital admissions due to chronic respiratory diseases, $25 \%$ reduction in hospitalizations due to diabetes; $38 \%$ reduction in emergency calls to patients with asthma, ${ }^{9-12}$ and $50 \%$ reduction in the occurrence of absenteeism due to arthritis. ${ }^{13}$

Thus, our study aimed to evaluate the epidemiological profiles and total health care costs of a group of patients with CDNCD at a Brazilian supplementary health service that was monitored by a CDMCP. As a secondary objective, we compared their hospital admissions and total health care costs with a group of patients not monitored by the program.

\section{Method}

A cross-sectional observational study with data provided by the CDMCP in the period from June 2010 to January 2012 (20 full months) was conducted. This program was part of the health care services provided to users registered with a health provider (HP) (classified as self-management) from the Brazilian Supplementary Health Sector, in accordance with the current regulations from the National Supplementary Health Agency (ANS). ${ }^{14}$ The CD$\mathrm{MCP}$ in this study consisted of a managing physician and a nursing assistant.

\section{Sample}

Only epidemiological data (gender, age group and ICD10 - International Classification of Diseases) and health care costs of the CDMCP users were accessed, and no other data that could identify individual patients under monitoring. This data was provided as computerized reports, which were part of the information technology service of the HP analyzed.

We selected 2107 users with CDNCD to take part in the CDMCP. After being selected, the patients were subdivided into two groups: Those who had chosen voluntarily to participate in the CDMCP and users who chose not to participate.

\section{CDMCP inclusion criteria}

Users were selected for having a CDNCD (according to the WHO definition). ${ }^{5}$ Users were invited to participate in the program by the CDMCP team or could be referred as instructed by the attending physician and/or other programs from the provider (such as a family medicine or home care service).

Users were invited for a consultation with the program's managing physician, and could freely choose to participate in the CDMCP or not. Non-participation in the program did not interfere or restrict user access to the accredited care services made available by the HP in any way, according to regulations of the Supplementary Health Sector. ${ }^{14}$ User participation in the CDMCP did not imply any pecuniary benefits of any kind to the patient.

\section{CDMCP exclusion criteria}

Users monitored by other programs offered by the HP (e.g. HomeCare) were excluded from the CDMCP so as not to interfere in the results of the CDMCP analyzed.

\section{CDMCP care flowchart}

The care flow of the CDMCP began with the identification of appropriate cases for the program through health care reports based on ICD-10 and indication of patients from other professionals at the HP. After identification of the target public, an initial consultation was scheduled with the managing physician of the program (provided with prescriptions and complementary examinations). The evaluations were individualized, as well as the user's monitoring plan. The managing physician checked the correlation between ICD-10 and the pathologies that the user presented, and sought the most appropriate strategy for each case, advising health education and self-management of the disease by the patient, encouraging them to increase adherence to treatment and suggesting possible non-pharmacological behavioral changes (such as healthy diet, weight control and regular physical activity) (WHO 2002). ${ }^{15,16}$ Patients were monitored through presential consultations (which could be weekly, fortnightly or monthly) and/or phone calls during the monitoring period. 
It is important to emphasize that patients remained under the care of their assisting doctors, who took the final decisions about clinical and therapeutic management. The managing physician of the program was responsible for defining the frequency of user assessment, according to the morbidities and the risk of complications of the existing CDNCD. There was no interference in the frequency of consultations defined by the attending physician. Therefore, the CDMCP studied was limited to informational and educational actions.

\section{Economic analysis}

To analyze the economic impact of the program, the actual total costs of health care in the group monitored in the program were compared with those of the group that chose not to be monitored. The total costs included medical and non-medical consultations (including the CDMCP), hospitalization, complementary examinations, surgeries, chemotherapy, radiation therapy and hemodynamic procedures. The costs were recorded in national currency (BRL) in the period analyzed. The absolute data (non-itemized total direct costs) were made available through accounting reports provided by the CDMCP. Indirect costs will be analyzed in another text.

\section{Statistical analysis}

Qualitative data (gender, age, ICD-10) were described using frequencies and percentages. Quantitative data from the costs were described using maximums, minimums, arithmetic means, standard deviations (SD) and 95\% confidence intervals (95CI) with significance at $\mathrm{p}<0.05$. The data was tabulated and analyzed using spreadsheets and charts (Excel ${ }^{\circledR}$ format from the Office $2007^{\circledR}$ system for Windows $\left.{ }^{\circledR}\right)$ and these remained at the disposal of professionals from the program and HP management.

\section{RESULTS}

Data from 2,107 cases were selected (1,018 women and 1,089 men, with an average age of 56 years), and these were divided into two groups: The 1,256 users who opted for the program (59.61\%) and the 851 patients who chose not to participate (40.38\%) (SD $\pm 286.37,95 \mathrm{CI}$ 1041.27-1065.73). The main characteristics are described in Table 1.

Six hundred and thirty-nine of the 1,256 study participants (51\%) were male and 617 (49\%) female, with gender distribution similarity (SD \pm 15.55 ; 95CI 627.14-628.26). Mean age was 56.9 ( $\mathrm{SD} \pm 17.65$; 95CI 56.01-57.96) years, ranging from one to 95 years; $73 \%$ of subjects were older than 50 years.

Three-hundred and seventy-nine of the 851 non-participants (44.53\%) were female, and 472 (55.46\%) male ( $\mathrm{SD} \pm 65.76$; 95CI 421.08-429.92). Their mean age was 56.2 (SD \pm 17.58 ; 95CI 55.46-56.97), ranging from one to 103 years; $73.27 \%$ of cases were older than 50 years.

In the CDMCP group, there were 428 (34\%) cases of ischemic heart diseases (coronary atherosclerotic disease and stroke), 210 (17\%) neoplasms, 151 (12\%) musculoskeletal disorders and 79 (6\%) metabolic diseases (diabetes, dyslipidemia, thyroid diseases) and the remainder was distributed within the total pathologies classified according to the ICD-10. In the non-CDMCP group there were $449(52.83 \%)$ cases of cardiovascular diseases and 80 (9.43\%) presented neoplasms.

Sixty-three percent of the participants (786) in the CDMCP were classified as holders of health insurance plans and 37\% (470) were classified as dependents.

In the CDMCP group, users had 1946 consultations in 290 months of monitoring, 690 (35.45\%) of which were return consultations in the program itself, with an average of 57.5 per month (SD \pm 24.93 ; 95CI 56.12-58.87). The majority of returns referred to cases of cerebrovascular diseases and/or neoplasms. Of these, $40.35 \%$ presented bi-monthly consultations with their attending physicians (consultations ranging from weekly to half-yearly).

The sum of the total number of days of hospitalization in the CDMCP group was 230 days compared with 1,097 days in the non-CDMCP group ( $\mathrm{SD} \pm 613.62,95 \mathrm{CI}$

TABLE 1 Clinical and demographic characteristics of the CDMCP and non-CDMCP groups.

\begin{tabular}{lllllll} 
Characteristics & CDMCP group & Non-CDMCP group & & & \\
\hline & $(\mathbf{n = 1 2 5 6 )}$ & $\mathbf{( n = 8 5 1 )}$ & Variance & Mean & Standard deviation $\mathbf{( \pm )}$ & $\mathbf{9 5 C l}$ \\
\hline Women & 639 & 379 & 33800 & 509.00 & 183.848 & 11.2936 \\
\hline Men & 617 & 472 & 10512.5 & 544.50 & 102.530 & 6.0896 \\
\hline Age (means) & 56.9 & 56.2 & 0.29645 & 56.6 & 0.544 & 0.0300 \\
\hline ICD (chapters) & & & & & \\
\hline (I) Cardiovascular diseases & 428 & 449 & 220.5 & 438.50 & 14.849 & 0.9828 \\
\hline (C) Neoplasms & 210 & 80 & 8450 & 145.00 & 91.924 & 10.5798 \\
\hline
\end{tabular}

ICD: International Classification of Diseases; CDMCP: chronic disease management care programs. 
630.51-696.49). There was an absolute reduction of $79 \%$ in days of hospitalization in the CDMCP group compared to the other group.

The total health care costs of the selected users were divided by gender, age group and ICD-10. In the CDMCP group, women accounted for 48\% (BRL 15,227,379.12), while male users were $52 \%$ (BRL 16,248,274.60) of the total cost of the program (BRL 31,475,653.72). That is, there was no significant statistical difference in health care costs between females and males (SD \pm BRL13,014.84, 95CI BRL13,086.34-BRL14,525.88). The greatest concentration of health care costs in the CDMCP group (51\%) was in the age group of 50 to 70 years (BRL 16,121,060.53) with a cost per patient of BRL 24,397.42. Cardiovascular diseases and neoplasms accounted for the greatest health care cost in the CDMCP group (64\%), with the cost per user classified as having a neoplasm at BRL 46,176.39 and cardiovascular diseases at BRL 24,536.40. CDMCP participants with health insurance (786) were responsible for $60 \%$ of the costs of the program (BRL 18,906,794.34) with the cost per patient with insurance at BRL 24,054.45 and per dependent patient at BRL 26,742.25.

The total cost of the CDMCP group in the period of 20 months was BRL 31,475,653.72 corresponding to $68.06 \%$ of the cost of patients in the non-CDMCP group (BRL 46,245,735.84). Despite the lack of statistical significance, the CDMCP contributed to an absolute reduction of $31.94 \%$ in total health care costs, with an $8.63 \%$ reduction in monthly costs, and a total reduction of BRL 40,529,349.28 (Table 2).

\section{Discussion}

In our analysis, we observed that the distribution of CDNCD patients with severe characteristics (frequent hospitalizations and/or emergency consultations in the year preceding the $\mathrm{CDMCP}$ ) and that needed CDMCP care was similar between genders and had a predominance of individuals aged over 50 years. These results are in accordance with the literature, ${ }^{5,13-16,18}$ which shows the similarity of the data studied in relation to the actual world population.
It is important to note that patients with a CDNCD are a heterogeneous population, with different medical care needs: $70-80 \%$ need only support and education for selfmanagement of their pathology, while a minority needs intensive hospital care. CDNCD patients, without proper monitoring or not adhering to treatment, have a high risk of complications, poorer quality of life and greater spending with high cost procedures in health systems. ${ }^{13,18}$ In the population studied, an absolute reduction was observed in number of days of hospitalizations (79\%) compared to users who had the same clinical conditions and chose not to participate in the program. The lack of individual monitoring of the population in the CDMCP group may be related to a higher number of hospitalizations and, possibly, lower adherence to non-pharmacological treatment measures.

The cost reduction observed was relevant: a $31.94 \%$ reduction in the total costs and $8.63 \%$ reduction in monthly costs, considering that the program evaluated in this study only offered verbal guidance to users, encouraging self-management of pathologies by patients, without interfering with the treatment plan established by the attending physician (in accordance with the fundamental elements of the programs based on the Chronic Care Model - $\left.\mathrm{CCM}^{17,18}\right)$.

In the same context, the ANS has established standards for Supplementary Health Plans in Brazil to offer users programs for chronic disease management, under Normative Resolutions No. 264 and $265 .{ }^{14}$ As noted in this study, it is possible to apply the CDMCP in the supplementary health sector, not only in the public system, with health care quality benefits and overall cost reduction.

In the context of Clinical Governance for continuous improvement of the quality in health care, ${ }^{19}$ the CDMCP analyzed in this study incorporated a focus on the individual and on health promotion for those being monitored by it. The health care provided by the case manager (observed in this study) including guidance and information for self-management of chronic pathologies respects the principles of clinical governance of completeness and fairness of the care, respecting the patient's autonomy.

TABLE 2 Clinical and demographic characteristics of the CDMCP and non-CDMCP groups.

\begin{tabular}{|c|c|c|c|c|c|}
\hline Characteristics & CDMCP group & $\begin{array}{l}\text { Non-CDMCP } \\
\text { group }\end{array}$ & & & \\
\hline & $(n=1256)$ & $(n=851)$ & Mean & Standard deviation $( \pm)$ & $95 \mathrm{Cl}$ \\
\hline Women & 639 & 379 & 509.00 & 183.848 & 11.2936 \\
\hline Men & 617 & 472 & 544.50 & 102.530 & 6.0896 \\
\hline Hospitalization (days) & 230 & 1097 & 663.50 & 613.062 & 32.9850 \\
\hline Cost (BRL) & BRL31,475,653.72 & BRL46,245,735.84 & BRL38,860,694.78 & BRL10,444,025.23 & BRL2,321.91 \\
\hline
\end{tabular}

CDMCP: chronic disease management care programs. 
Thus, CDMCPs can be regarded as a mechanism capable of adding value to the health provider, rationalizing the use of resources and providing quality health care.

\section{Conclusion}

Multidisciplinary monitoring through CDMCPs of CDNCD patients can reduce hospital admissions, emergency consultations and complications, positively impacting the costs of health care.

\section{Resumo}

Gerenciamento de casos crônicos: governança clínica com redução de custos

Introdução: com o crescente impacto mundial das doenças crônico-degenerativas não transmissíveis (DCDNT), os programas multidisciplinares de gerenciamento de pacientes com doenças crônicas (PGDC) apresentam-se como uma solução para melhorar a qualidade do atendimento prestado.

Método: foi realizado um estudo epidemiológico, tipo coorte, prospectivo, com dados comparando um grupo em acompanhamento em um PGDC com um grupo sem esse acompanhamento, no período de 2010 a 2012. Usuários acompanhados pelo programa eram selecionados por serem portadores de DCDNT, com internamentos e/ ou consultas em serviços de emergência frequentes no ano anterior à seleção; por indicação do médico assistente e/ou outros programas como HomeCare ou medicina da família. Foram contabilizados todos os custos relacionados com assistência em saúde do programa e comparados com os custos de usuários com mesmo perfil epidemiológico que optaram pelo não acompanhamento no programa.

Resultados: foram selecionados dados de 1.256 casos, sendo 639 (51\%) do sexo masculino e 617 (49\%) mulheres. A média etária foi de 56,99 e $73 \%$ dos casos acima dos 50 anos. Predomínio de 34\% (428) de casos de doenças cardiovasculares isquêmicas (infarto do miocárdio e acidente vascular cerebral) e 17\% (210) de neoplasias. Os casos acompanhados apresentaram redução de $79 \%$ dos dias de internamento em comparação com casos não acompanhados. A redução média de custos totais (internamentos, consultas de emergência e/ou complicações) foi de 31,94\%, com redução média mensal de custos de 8,36\%.
Conclusão: acompanhamento multidisciplinar em programa de gerenciamento de pacientes portadores de DCDNT pode reduzir internamentos, consultas de emergência e complicações, impactando positivamente nos custos da assistência à saúde.

Palavras-chave: doença crônica, gestão em saúde, custos de cuidados de saúde, governança clínica.

\section{References}

1. Gonzales RIC, Casarin SNA, Caliri MHL, Sassaki CM, Monroe AL, Villa TCS. Gerenciamento de caso: um novo enfoque no cuidado à saúde. Rev Latinoam Enferm. 2003; 11(2):227-31.

2. Santos Filho OC. Gerenciamento de saúde. Porto alegre: SOMAERGS, 2003

3. Mendes EV. Auditoria clínica. Belo Horizonte, 2003.

4. Mendes EV. A atenção primária à saúde no SUS. Fortaleza: Escola de Saúde Pública do Ceará, 2002.

5. Organização Mundial da Saúde (OMS). Prevenção de doenças crônicas: um investimento vital. 2005. Available from: http://www.who.int/chp/chronic disease_report/part1_port.pdf.

6. Saúde Brasil 2008: 20 anos do Sistema Único de Saúde (SUS) no Brasil Ministério da Saúde, Secretaria de Vigilância em Saúde, Departamento de Análise de Situação em Saúde. Brasília: Ministério da Saúde, 2009.

7. Alliota SL. Case management of at-risk older people. In: Cochrane D. Managed care and modernization: a practioner's guide. Buckingham: Open University Press, 2001.

8. Teixeira S, Palma Reis I, Mirco A, Fernandes J, Rodrigues T, Lynce A, et al Caracterização dos doentes de baixo risco internados por Pneumonia Adquirida na Comunidade (PAC). $1^{\circ}$ Congresso Ibérico de Medicina Interna. Lisboa, 2007

9. Doughty RN, Wright SP, Pearl A, Walsh HJ, Muncaster S, Whalley GA, et al Randomized, controlled trial of integrated heart failure management: The Auckland Heart Failure Management Study. Eur Heart J. 2002; 23(2):139-46.

10. Bourbeau J, Julien M, Maltais F, Rouleau M, Beaupré A, Bégin R, et al. Reduction of hospital utilization in patients with chronic obstructive pulmonary disease: a disease-specific self-management intervention. Arch Intern Med. 2003; 163(5):585-91.

11. Griffiths C, Foster G, Barnes N, Eldridge S, Tate H, Begum S, et al. Specialist nurse intervention to reduce unscheduled asthma care in a deprived multiethnic area: the east London randomised controlled trial for highrisk asthma (ELECTRA). BMJ. 2004; 328(7432):144.

12. Vrijhoef HJ, Spreeuwenberg C, Eijkelberg IM, Wolffenbuttel BH, van Merode GG. Adoption of disease management model for diabetes in region of Maastricht. BMJ. 2001; 323(7319):983-5.

13. England UK National Health Service. Chronic disease management: compendium of information, 2004.

14. Agência Nacional de Saúde Suplementar. [cited 2013 Nov 18]. Available from: http://www.ans.org.br.

15. WHO. Innovative care for chronic conditions: building blocks for action: global report. Genève: World Health Organization, 2002.

16. OMS. Cuidados inovadores para condições crônicas: componentes estruturais de ação: relatório mundial. Brasília: Organização Mundial da Saúde, 2003.

17. Mendes EV. Revisão bibliográfica sobre redes de atenção à saúde. Brasília: Ministério da Saúde, 2011.

18. Mendes EV. O cuidado das condições crônicas na atenção primária á saúde: o impacto da consolidação da estratégia da saúde da família. Brasília: Organização Pan-Americana de Saúde, 2012.

19. Oliveira FB. Gestão da clínica e clínica ampliada: sistematizando e exemplificando princípios e proposições para a qualificação da assistência hospitalar. [Dissertação]. Rio de Janeiro: Escola Nacional de Saúde Pública Sergio Arouca, 2008. 